\title{
Italy's Recipe for Coming out of Debt Crisis: Reform Packages
}

\author{
Prof. Dr Serap Durusoy ${ }^{1} \&$ Zeynep Beyhan ${ }^{1}$ \\ ${ }^{1}$ Faculty of Economics and Administrative Sciences, University of Abant İzzet Baysal, Bolu, Turkey \\ Correspondence: PHD Zeynep Beyhan, Faculty of Economics and Administrative Sciences, Abant Izzet Baysal \\ University, Golkoy Campus, Bolu 14280,Turkey.
}

Received: November 19, 2015

doi:10.5430/rwe.v6n4p104
Accepted: December 15, 2015 Online Published: December 20, 2015

URL: http://dx.doi.org/10.5430/rwe.v6n4p104

\begin{abstract}
The crisis that came about in Greece in the year 2009 took the European markets under control in a short time and turned into Euro Debt Crisis. Among the economies that are swept into recession by the crisis, Italy is the leading economy. Political depression combined with the shrinkage recorded in its economy dragged the country into chaos. In the fast spreading of the crisis in question, problems created especially by Italy's own inner dynamics are regarded as to have impact. In that context, following the resignation of Berlusconi in the year 2011, Mario Monti, Enrico Letta and lastly Matteo Renzi Government that has been in the office since the year 2014, has emphasized the necessity of permanent and radical reforms and taken steps towards this direction.

Here in this study, it was studied how effective the reform packages consulted by the three governments that have been changing since the year 2011 in solving the structural problems of Italy and saving it from the debt crisis. In addition, the sufficiency of the reform packages that were put into practice were analyzed and alternative solution offers concerning what should be done were proposed.
\end{abstract}

Keywords: economic reforms, the economic policies of Italy, debt crisis

\section{Introduction}

Italy's negative economic outlook before its membership in Euro Zone continued even after its membership to Euro zone. Such that, gradual weakening of the country's economic structure and not being able to get rid of the weakening in question through palliative solutions obliged radical and structural change. The unbalancing of the economic balance especially after the crisis and the debt burden reaching unsustainable sizes triggered the governments to apply reform packages that will contribute to the country's economy in the long run and will save from the difficult situation it is in.

The ex-Prime Minister of Italy, Silvio Berlusconi, has had an enormous impact on the current political tension and economic uncertainty in the country. Since the time of Berlusconi, who was allegedly involved in corruption through his association with illegal organizations, Italy has been under the rule of three governments, led respectively by Mario Monti, Enrico Letta, and Matteo Renzi, all of which had the common view that Italian economy needed a structural transformation.

Firstly, this study aims to examine the effects of the structural problems in Italian economy along with the Euro debt crisis on Italian economy. With particular attention attached on Maastricht Convergence Criteria, it is aimed to demonstrate that economical problems in Italy have their roots long before the debt crisis. On the other hand, it has been observed that one of the structural problems is the stagnation of growth caused by the loss of competitive capacity that arose following the country's incorporation into the Euro-group. It is also aimed to examine the reform packages implemented with a view to resolving the economic crisis. Following a discussion of the effectiveness of the reformist steps taken based particularly on structural problems as part of government programmes, alternative solutions for the issue have been proposed.

\section{General Economic Outlook: Economic Balances Changing with the Debt Crisis}

Euro Crisis, which came out in Greece in the year 2009 and affected the whole Europe in a really short time, made its presence after Portugal and Ireland felt in Italy, which has the $4^{\text {th }}$ biggest economy in Europe with its GDP (Gross Domestic Product) of 2 billion Dollars. Economic recession experienced in Italy with the effect of the crisis turned the economic scale and the country stared to be swiftly dragged towards crisis. However, when the origins of the 
crisis wave in question are analyzed, the situation is understood to be much more serious than how it seems. Together with the process that started with 11 members of the European Union, of which Italy is also a member, switching to Euro in the year 1999, risks that increased cumulatively in Italian economy and the dominant political instability therewhen combined with the Euro Crisis dragged the country step by step into chaos. Within this process, companies that shut down quickly in the North and South parts of Italy increased unemployment, and the youth unemployment that shows serious tendency to increase turned country's outlook into a negative one (Table 1) (www.istat.it).

Table 1. Italy unemployment rate (2010-2014)

\begin{tabular}{lccccc}
\multicolumn{1}{c}{ Years } & $\mathbf{2 0 1 0}$ & $\mathbf{2 0 1 1}$ & $\mathbf{2 0 1 2}$ & $\mathbf{2 0 1 3}$ & $\mathbf{2 0 1 4}$ \\
\hline $\begin{array}{l}\text { Total } \\
\text { Unemployment } \\
\text { Rate }\end{array}$ & 8,4 & 8,4 & 10,7 & 12,2 & 12,7 \\
\hline $\begin{array}{l}\text { Youth } \\
\begin{array}{l}\text { Unemployment } \\
\text { Rate }\end{array}\end{array}$ & 27,9 & 29,2 & 35,3 & 40,0 & 42,7 \\
\hline
\end{tabular}

In especially making Italy the focus point of crisis, its being part of Euro though it could not meet the economic adjustment criteria called as Maastricht Criteria in Maastricht Treaty, which is considered as the founding agreement of European Union, plays an important role. Within the period between deciding the creation of European Union (1993) and entering into effect (1999), the countries that would be included in the union were expected to meet certain economic criteria as seen in Table 2. In this context, the inflation rate of the countries, the rate of public deficit to GDP, rate of public debt stocks to GDP, macroeconomic approach criteria in relation to the stability of interest and foreign exchange rate were all determined within the frame of the treaty and the countries were required to meet these criteria to be able to switch to Euro and be part of Euro Zone.

Table 2. Maastricht convergence criteria (European Commission, 2007)

\begin{tabular}{lcc}
\hline \multicolumn{1}{c}{$\begin{array}{c}\text { What is } \\
\text { Measured? }\end{array}$} & $\begin{array}{c}\text { How It is } \\
\text { Measured? }\end{array}$ & Convergence Criteria \\
Price Stability & $\begin{array}{c}\text { Harmonized } \\
\text { Consumer Price } \\
\text { Inflation Rate }\end{array}$ & $\begin{array}{c}\text { Not more than 1.5 percentage points above the rate of the three best } \\
\text { performing Member States }\end{array}$ \\
\hline $\begin{array}{l}\text { Sound Public } \\
\text { Finances }\end{array}$ & $\begin{array}{c}\text { Government } \\
\text { Deficit as \% of } \\
\text { GDP }\end{array}$ & Refernce Value: Not more than $3 \%$ \\
\hline $\begin{array}{l}\text { Sustainable } \\
\text { Public Finances }\end{array}$ & $\begin{array}{c}\text { Government Debt } \\
\text { as \% of GDP }\end{array}$ & Reference Value : Not more than $60 \%$ \\
\hline $\begin{array}{l}\text { Durability of } \\
\text { Covergence }\end{array}$ & $\begin{array}{c}\text { Long-Term } \\
\text { Interest Rate }\end{array}$ & $\begin{array}{c}\text { Not more than 2 percentage points above the rate of the three best } \\
\text { performing Member States in terms of price stability }\end{array}$ \\
\hline $\begin{array}{l}\text { Exchange Rate } \\
\text { Stability }\end{array}$ & $\begin{array}{c}\text { Deviation from a } \\
\text { central rate }\end{array}$ & Participation in ERM for two years without severe tensions \\
\hline
\end{tabular}

However, though it was underlined that countries that cannot comply with the criteria would not start using Euro, Italy, which was one of the leading countries that could not even pass near the criteria in question, was accepted into European Union and its unsuccessful performance was ignored. Eventually, the public debt / GDP ratio, which must not surpass $60 \%$, was recorded as $118 \%$ in the year 1999, when Italy became part of European Union, and the fact that this high rate was preserved and the public debt cumulated in time caused the creation of risk over the economy. In Italy, where the public debt / GDP ratio was $112.5 \%$ in the year 2009, when especially the European Crisis started 
to show its effect over economies, this rate reached $116.4 \%$ in the year 2011 and increased its speed in the last three years by reaching $132.1 \%$ (Table 3 ) (http://ec.europa.eu/eurostat).

Table 3. Italy government debt/ GDP(\%) (1999-2014)

\begin{tabular}{lllllll}
\hline Years & 1999 & 2002 & 2005 & 2009 & 2011 & 2014 \\
\hline $\begin{array}{l}\text { Government } \\
\text { Debt }\end{array}$ & 118 & 107.9 & 106.2 & 112.5 & 116.4 & 132.1 \\
\hline
\end{tabular}

Another factor that played an important role in dragging Italy into crisis is the fast decreasing interest rate that occurred with the inclusion into European Union. When the 5-year-long interest rate average in the years 1992-1996 when Euro was not used was compared with the interest rate occurred after Euro getting into circulation, serious differences strikes one's eyes. It is observed that the long-term interest rate that took place in the rate of $11.3 \%$ during the use of Liret in Italy before Euro dropped as a result of switching into Euro. Actually the decrease in interest rate that occurred with the inclusion to Euro Zone is the result of the single currency policy that was pursued. European Central Bank's (ECB) running the money policies of all the countries which are part of Euro Zone exclusively necessitated a common interest rate and integrated the money markets of these countries. Countries included in the Euro Zone reached an interest rate that is way lower than the rate of $7.8 \%$ previously determined in Maastricht Criteria, and they presented each other convergence to a large extent. Besides, it was stated in the Article 121(1) of the Treaty Establishing the European Community that the long term interest rates would be calculated on the basis of 10 year-long government bond interest rates of the countries. Accordingly, the change in the bond interest rates shows the changes in countries' costs of borrowing. Since the interest rate that was approximately determined by ECB to be valid for all the countries after their entry into Euro system also determined the interests of borrowing of these countries; the borrowing interests of the countries that would be part of the Euro zone were arranged by taking the interest rates of Germany's government bond which seem to have a less risky economy outlook in comparison to other countries in the region. Therefore, Italy being in the first place, countries excluding Germany before being part of the Euro system paid their interests with high figures such as $20 \%$ for Greece and $11 \%$ for Italy, these economies benefited Germany's reputation after being part of Euro Zone and started to pay their interest with lower figures. Though this situation presented the money policy ran by ECB from a single center as if it was successful, in reality the fiscal discipline was seriously damaged from this situation (Eğilmez 2012).

On the other hand, as it can be seen in Table 4, the drops occurring in the growth rates show that Italian economy entered into recession. The country, which showed a growth rate of $1.0 \%$ in the year 2007 showed a significant recession with the start of year 2008, and its growth rate regressed up to the rate of -5.9 in the year 2009 .

Table 4. Italy growth rate (1999-2011)

\begin{tabular}{cccccccccc}
\hline Years & 1999 & 2001 & 2003 & 2005 & 2007 & 2008 & 2009 & 2010 & 2011 \\
\hline GDP & 1.5 & 1.7 & -0.3 & 0.5 & 1.0 & -1.7 & -5.9 & 1.4 & 0.6 \\
\hline
\end{tabular}

In addition to the creation of recession by crisis in economy, cumulative problems caused by Italy's economy's own inner dynamics had also an important contribution to the recession in question.

Indeed, while Italy's economy, which was built on the focus of branding in textile sector, was growing rapidly between the years 1980-1990, it was observed that this rate gradually dropped throughout the 90s. Though there were quite drastic drops observed in the growth rates of the first half of the 1990s, especially since its participation in European Union in 1999 there have been serious regression in the rates in question. One of the biggest reasons for this big drop in economy is Italy's rapid loss of competitive power. Experiencing an important competition loss against Germany especially with switching to Euro, Italy could not strengthened the power it acquired up to the beginning of the 90s and it was defeated against Germany's competition. The extent of Germany's capacity in capital and creating technology-oriented production provided serious advantages to the country and its profit margin rose with the increase in its labor productivity. Along with the advantages provided by EPB, benefiting also from the economic inequalities within EU, Germany increased its production capacity rapidly and became the dominant country of EU. In this context, competition loss of Italy, which provides current deficit at the same level with 
Germany provides current surplus, weakened the outlook of the country and the distance between Germany gradually widened. While especially the costs per unit drops rapidly in Germany, Italy's experiencing directly the opposite of this is one of the main reasons for losing its competitive power against Germany. Hence, since switching to Euro as currency up to this point, Germany has increased only its labor cost up to the rates of $20 \%$, while in Italy this rate was $35.3 \%$ and it created a big obstacle against its growth by discouraging economic competitive power. Therefore real sector efficiency and production volume also dropped gradually (Manasse 2013).

Besides more than multinational companies, having small family businesses as majorities also weakened the competitive power of Italy after every passing year. In Italy, where the number of small-scaled and big-scaled companies are quite a lot; this situation caused one product to become prominent in the production sector. Majority of the small-scaled and big-scaled companies in Italy in question are family companies. These companies, which have a great importance in country's economy, make up almost $99 \%$ of all the companies (European Commission 2008: 4). However, since these family sectors are small businesses they could not find its place in the international platform against German and Chinese economy that have been rapidly increasing especially in the last ten years and lost its competitive power.

Discrimination between North and South which is dominant in Italy and could not be defeated for many years also created an obstacle against growth and became one of the principal problems of the country. These problems, which have been among North and South Italy where serious differences among important macroeconomic data such as unemployment rates and per capita income exist, have divided the country into two. While improved industry and rooted and rich private companies are prominent in the North, the Southern parts of the country come to the forefront with their state-sponsored agricultural areas and small-scaled industrial areas. Since South Italy, which is called in Italian as "Mezzogiorno", is weaker than the North in terms of economic development, it was aimed to improve Mezzogiorno with the relief fund created by the government as "La Cassa del Mezzogiorno" (http://www.treccani.it, It was accessed in 1 February 2014). While the public expenditures made in North Italy in the last fifteen years are about the rate of $40-45 \%$, the rate of public expenditures in the South is around $55 \%$. However, transfers which were made in South by cutting down on public expenditures to be made in the North and which equal to $4 \%$ of the national GDP could not be made use of in an efficient way and they were directed to wrong circles of trade. The fact that the biggest cause for that was the distribution of the relief made available by the country's administration was under the control of the local administrative of Southern cities, caused wrong distribution of resources (Trigilia 2012: 141). In this regard the program, which was unsuccessful due to the extravagance of the local administrations and not being able to use the resources effectively, was highly criticized by North Italy. For, while the people working in North Italy made a big contribution to state's budget by working overtime, the Southerners could not make a big contribution to the state budget by merely working for 6 hours a day and in addition, the fact that majority of the resources earned by the Northerners were transferred to South Italy and the transfers in question could not be used effectively due to arbitrary behaviors of the Southerners took the already existing North - South culture conflict into an economic level. Besides, though the investments made in the North are almost two times of the investments in South Italy, the fact that Southerners spend as much as the Northerners is one of the leading causes that awakens anger in the public of North Italy and also has become a chronic conflict between North and South (Bohlen,1996).

On the other hand, another dimension of the conflict between North and South is made up of underground economy, which has become the chronic problem of the country over the years. Illegal economic activities, which are more common in South Italy rather than North Italy, are run by certain "Italian Mafias" and cause the creation of unrecorded economy(Floris 2010: 156). Unrecorded economy, which consists of about 7\% to 8\% of GDP, impacts country's outlook negatively and emerges as a structural problem facing growth. It was found out that huge sums of money were transferred to "Casa Nostra", which infiltrated all the units in South Italy and is known to be one of the leading illegal organizations in question that is known to have connection particularly with the Former Prime Minister of Italy Silvio Berlusconi and his right hand Former Senator Marcello Dell'Utri along with many other Italian politicians and known to be Sicilian mafia (http://www.ilfattoquotidiano.it). After the news about Former Prime Minister Berlusconi was revealed, it was found that the members of the mafia, which is determined to be in close relationship especially with the local municipalities, confiscated about $35 \%$ of the reliefs provided under the fund names "La CassaMezzogiorno", which was created to develop the Southern part of Italy by the government (Barone andNarciso, 2012).Transferring this resource, which was created for the development of the southern part of the country, to the illegal organizations in question created a grave obstacle against the growth of Southern part's and thus the Italy's economy.

With the addition of political tension as a result of the resignation of four ministers from the coalition wind near the end of the year 2010 to all these instabilities present in Italy created chaos in the country and created an insecure 
environment. This condition led the way for three big international credit rating agencies, Fitch, Moody's and S\&P to make a discount in grades for Italy (http://www.soldionline.it). While still the Italian markets, having been shocked by the grade discounts of the agencies in question, could not yet shake off this effect, it experienced another shock with the resignation of Prime Minister Silvio Berlusconi as a result of the budget that included economic reforms suggested by EU in 2011 November was accepted in the House of Representatives with 380 "Ayes" and 26 "Nays". 5 year-long Italian government bond interests within this process affected country's outlook by passing the $7 \%$ psychological limit and reaching 7.5\%. In this regard, negative process in Italy, which got stuck between economic depression and political instability, instigated panic and dragged the country into Euro Debt Crisis. It was understood that Italy could not save itself from this condition it reached over the years with temporary precautions and the necessity to execute the reforms that would find solutions to country's structural problems came to light. Thus, since the year 2010, 4 reform packages have been put into practice during the period before Mario Monti, during Mario Monti, during the period of Enrico Letta and lastly Matteo Renzi.

\section{Period before Mario Monti: Reform Package Approved by the Parliament in the Year 2010}

"Financial Stability Act", which included strict austerity precautions in order to decrease the budget deficit of 2011 September and to support the growth, was approved by the House of Representatives in 11 November 2011. Approval of "Financial Stability Act", which caused the resignation of Prime Minister Silvio Berlusconi (La Repubblica), by the parliament, increased the hopes in country's saving itself from the economic crisis environment. Meeting the economic reform requirements that are also requested by the EU, the act in question was arranged in a package mainly with austerity policies that Italy was not so much familiar with before. In the package predicting putting real estates owned firstly by the government up for sale, it was designed to use the income acquired there for decreasing the public debt. Afterwards, with the package in question it was ensured to take steps that will encourage the privatization of the regional and local administrations and affiliates providing public service, and thus privatization policies were underlined.On the other hand in order to support the highway constructions, it was decided that infrastructure companies would receive full or partial tax incentive in their highway constructions. In the package, which included decisions that increase youth's participation in employment, there were articles regarding the companies that will benefit from the full tax incentives for the youth they will employ through contracts of apprenticeship dated between January 2012 and December 2016. Again, the decisions about providing flexibility for directing the labor surplus in the public sector towards different works by making reforms regarding the employment market were taken. In addition to all these, putting more serious action plans into practice to increase of retirement age from 65 to 67 was a decision of the government taken within the frame of austerity precautions (Messia and Chance: 2011).

\section{Mario Monti's Reform Packages}

Following Berlusconi's resignation, Italian Economist Mario Monti was given the duty by the President of Italy to form a government and Monti assumed the duty of a prime minister by forming "Technocrat Government" made up of people who are experts in their field in 16 November 2011 (http://www.storiaestorici.it/). Mario Monti aspired to build the trusts of the markets again and to settle the political tensions in the country (http://www.ilmessaggero.it/PRIMOPIANO/). Monti in his reform package, which he announced after taking over prime ministry, emphasized the necessity of applying the structural reforms in Italy and stated the need to minimize the lack of growth and competitive power and the high costs per unit in no time. Determining his reform agenda under three main platforms as "Austerity", "Growth" and "Justice", Monti underscored that the behaviors of investments who play an active role in determining the level of interest rate of Italian bonds during the actualization process of the reforms would be taken into consideration.Also he stated that the views of European Union Policy makers who play an important role in ensuring the trust between parliamentarians and public would be adhered to (La Repubblica). Monti Government explained these reforms it designed within the context of four main packages.

\subsection{Salva Italia}

Having been approved in 4 December 2011, the reform package included changes in relation to fiscal policy and retirement system (GovernoItaliano 2011). Reform package, which was prepared for taking steps towards encouraging fiscal consolidation and growth, aimed to improve the budget balance up to the year 2013 at a level of 34 billion Euros. It was estimated that especially the improvements in product and labor markets will contribute to the budget balance more than 10 billion Euros.

Government, which is going under serious changes in terms of how the public spending and incomes will be managed for the actualization of the targets determined within the frame of austerity package called as Salva Italia, consulted strict austerity policies. Attempting rises in the taxes within the scope of increasing public incomes, Monti 
Government increased fuel oil tax and also brought additional taxes to luxurious goods as well. In addition, it was decided to receive tax from the local municipality buildings and to decrease regional government transfers within the scope of Salva Italia (http://www.unionelarioemonti.it).

In the prevention package, where it was also emphasized that there will be regulations for increasing the competition in good and service market, it was stated that infrastructure investments would also be supported. Thanks to the regulations towards retirement system which constitute one of the parts of reform package, it was designed to achieve savings up to the year 2014 at an amount of 8.5 billion Euros. Changing the retirement age from 62 to 70 for female workers and 66 to 70 for male workers in addition to decreasing the retirement salaries, government tried to increase the participation of the people aged over 60 to the labor and targeted to decrease the appeal of retirement (Cencig 2012: 37).

In addition to all these, having succeeding in creating a never-before-seen radical change in Italy's political map, Monti Government planned to save 40 million Euros annually in the public budget by decreasing the number of cities in the country from 86 to 51 . By this means, 35 cities, which were established in an area of 2500 square meters with a population under 350 thousand lost its status as a city and became part of near-by cities. With the changes that would be effective as of 1 January 2013, when cities that have special statues outside the scope and some metropolises are added together, the number of cities decreased from 110 to 75 (Corriere Della Sera).

\subsection{Cresci Italia}

This reform package which was approved in 20 January 2012 included regulations that encouraged growth for eliminating country's problem of competitive power. The package was built on a series of liberalization precautions in order to enhance economic initiative and solve problems caused by the administrative burden. It was planned to remove significant amount of restrictions over permission and authority which were especially needed to start a business. Thus, thanks to the simplified applications, the entrepreneurs were encouraged and their way was paved to establish companies (Normattiva).

On the other hand in the Cresci Italia reform package, which included precautions against service sector, it was decided by the government to remove the obstacles in front of the young workers against receiving internship education in the areas they want to specialize in for analyzing the areas in question during their postgraduate educations which would ease their entry to labor market. Besides, for strengthening the private capital investment in infrastructure constructions it was decided to create "project bonds" and conditions for creating addition funds in order to empower the competition in bank and insurance sectors were tried to be created (http://www.dirittobancario.it).

\subsection{Semplifica Italia}

Being accepted at the end of January in the year 2012, this reform package planned to especially strengthen the relationship between the government and the citizens and to prevent bureaucratization by creating institutions that give importance to innovation and that keeps in tune with the times. Reform package was prepared in accordance with the suggestions coming from European Commission and it targeted to overcome the long-term growth problem by consulting new technologies that contribute to the increase of efficiency.

On the other hand, the financial regulations concerning the taxes that make up of the second part of the reform package was approved by the Government in 24 February 2012.For the purpose of encouraging the struggle against tax evasion, the tax deductions were decreased and more changes were made over the tax laws (Governo Italiano 2012)

\subsection{Reform Packages towards Labor Markets}

The most controversial reform package applied by Monti Government was towards labor markets. Apart from the protests of labor unions against the package, which included strict precautions, it was also defended in the parliament that the package in question had very strict precautions against labor markets and thus some articles were softened and they were put into vote. The basis of the reform package was built on some regulations that opened the way for "catalyzing the dismissal of the workers".Making changes that none of the governments dared to change up to the Monti Government over the $18^{\text {th }}$ Article of Labor Law, which obligates the re-hiring of the worker that was dismissed if the jurisdiction spots wrongful dismissal, government interpreted the regulations they actualized as a "historical reform" that is expected to provide a perspective towards economic growth and to create an inclusive and dynamic labor market. According to this, the reform that recognizes the right given to the judges to order the re-hiring of the worker in case the reasons for dismissing "disappears clearly" obliged, with its older version in March, to merely pay the compensation and did not mention anything about the subject of re-hiring. Reform 
package, which was the target of many criticisms with its new version, was assumed to incite the trust issue felt about the future of the country due to the young workers' being obliged to short-term contracts that promise no career development whatsoever. There were lots of criticisms directed towards the reform package created for the labor markets. The criticisms were especially focused on the one hand though there are long-term and permanent contracts whose borders are determined definitely but are expensive and provide a lot of rights for the employees that the employers cannot accept, and on the other hand the existence of a parallel labor market which consists of short-termed and extraordinary contracts that earn very little money and offer very few rights (http://www.euronews.com).

Unlike the ones expressing negative opinions about the reform package and defending that the labor market will go downhill, it was observed that there were some opinions stating that the latest regulations would be reflected on the country positively. In that context, having received the full marks especially from the company owners, this reform package was seen as a great success accomplished by the Monti Government. Pointing out the necessity to conduct the reforms in the Southern part of Italy where the majority of the youth were unemployed, the Minister of Labor Elsa Fornero stated that the positive sides of the regulations in question were dominant. Fornero, defending that the reform package approved by Monti Government as balanced, she stated that not only the dismissal of the workers but also the supports that would be provided for the unemployed would be increased and also emphasized that by this means the reform could provide an opportunity to find a new job.

Likewise, with the "Anti-Corruption Act" accepted in 30 October 2012, it was aimed to eradicate the destructive impact of corruption over economy and to fix the image of the country. In Italy, where corruption cause the economy to lose minimum 60 billion Euros in a year, the prison sentences to be given to the public officers who accept bribe or who abuses his position were increased with this act. Besides, it was banned for the people sentenced for corruption to assume a public office and it became obligatory for the local administrative to announce their budgets over the internet (Angelis, 2012).

As can be seen, Mario Monti Government, which succeeded in creating many reforms throughout the period it was running, took crucial steps in especially bringing the environment of trust back in Italy. However, after Former Prime Minister Silvio Berlusconi and the political party People of Freedom (PDL), whom he was leading, withdrew their support from the technocrat Mari Monti Government, Monti resigned by stating that there was no environment of trust was left for his government and Enrico Letta from the Democrat Party became the new prime minister (https://www.wsws.org/it).

\section{Enrico Letta's Reform Packages}

Central left Democrat Party's Party President Enrico Letta, after having been tasked with forming the government in February 2013, stated that there would be new steps taken for a new start for Italy. Criticizing that the governments that were in charge for the past twenty years in Italy tried to solve Italy's problems by finding temporary solutions, Prime Minister Letta focused more on the structural reforms than on austerity policies in the new term (Governo Italiano 2013).

Emphasizing that the elections law, which was on the firing line of the country constantly, would undergo some reforms in the new coalition agreement that would be prepared firstly in 2014 January, Letta stated that there would be arrangements for decreasing the number of representatives in the parliamentary system in order to provide a political stability in the country. In addition, Letta announced the new reforms on the way for the taxes, and stated that there would be some regulations concerning the taxes started by Mario Monti and that dissuade the companies from hiring new employees (http://www.bbc.com). Indeed with the announcement of property tax removal, Letta came into conflict with the tax policies of Mario Monti Government before him (http://archivio.internazionale.it).

Constantly emphasizing the necessity for giving importance to structural reforms ever since his election in 2013 February, Letta clearly underlined that the youth employment reached critical numbers and regulations to prevent that would be accelerated. Also stating that reform preparations towards providing more participation for the labor force by increasing the women employment, he aimed to bring permanent solutions to unemployment, which follows a rapidly increasing course in the country. Together with the regulations prepared by Letta Government, it was aimed for the country to escape the recession which was dominant in the country and to record an economic growth of $1 \%$ in the year 2014 and 2\% in the year 2015 (Governo Italiano 2013).

As can be seen, the Government's reform package which was known in general terms to deal with taxes and structural problems preventing Italy's growth was criticized by the people who thought that package did not sufficiently focus on the structural problems. The fact that public debt and reform applications towards public sector, 
which were among the leading problems of Italy, not mentioned in the package though they should have been on the top of the list increased the concerns over the possibility that Letta Government could not be sufficient to find solutions to structural problems.Besides, it was another point of criticism when the regulations concerning infrastructure and innovations, which embodied the key role in enhancing the growth, were given a little place. On the other hand, the reform pertaining to the removal of property tax was seen as a regulation that was tried to be established on a base that had no grounds accepted by many of the people. In fact, IMF and OECD were among the most important institutions that reacted to this situation. Stating that Italian Government would have serious difficulties in covering the deficits by giving up on collecting property taxes and this would increase the shortage of cash in which the country finds itself, the institutions in question emphasized that Italy took a wrong step that would not allow its economic structure to handle (Dinmore and Segreti, 2013).

Seeing that Enrico Letta could not meet the promises he gave via slogan called "A New Italy", the public started rioting everywhere in the country. Upon losing the support of Democratic Party, which as its big partnertook part of the right-left based coalition government that Enrico Letta was a member of, Letta announced its resignation in 13 February 2014. Thereupon Matteo Renzi from Democratic Party, having the majority of Italian parliament, was assigned to form the new government (Gagliardi, 2014).

\section{Matteo Renzi's Reform Packages}

Innovation oriented views of Renzi, who would preside over the 63rd government, promised hope for the difficult situation Italian economy finds itself in (http://www.ilfattoquotidiano.it).

Reform program announced by Renzi in Republic Senate focused on the subjects that were the common concerns of all the parties such as immediately enacting the elections law, employment, radical reforms in the fields of education, finance and justice and also decreasing the public debts which exceed two trillion Euros. Having the regulations found in the reform package approved in the parliament in a very short time, coalition government under the presidency of Renzi on the contrary took action faster than the previous Letta Government.However, having received serious reactions from the public due to the regulations concerning especially education and labor act, Renzi Government was protested by unions, workers and teachers through their strikes (http://www.tgcom24.mediaset. it).

First of all by accepting the new "Labor Act" that would make discharging the people working in the private sector easier in order to create employment and flexibility in the labor market, the flexibility was provided on behalf of the employer in terms of terminating worker's contract of employment. In response the work and labor unions, which argued that worker rights wereviolated, called for strikes in the middle and northern part of the country and stated that there could be no acceptable part on behalf of the workers belonging to the act passed in the parliament by Prime Minister Matteo Renzi and his government without taking the opinions of the workers.

Regulations found within the Renzi Government's reform package concerning the education that are called as "La Buona Scuola" (Good School) also got big reactions from the educational institutions. The reform package, which included subjects as granting more authorization to school principals, having some workers in the education sector into the temporary staff, encouraging the establishment of private schools, cutting the budget for the maintenance of the buildings belonging to state schools and increasing the hour of internship in the high schools, was objected by the unions and teachers working in the sector for the reason that it "would raise social and regional inequality and did not include the fundamental regulations needed by the field of education".Stating that the reform package in question would be reviewed by considering the strike and protest news heard from all parts of the country, Prime Minister Renzi and Minister of Education Stefania Giannini reported that they would establish a dialog with the parties of the events (http://www.giornalettismo.com).

In addition, having remarked that the previous Enrico Letta Government before him was mistaken in removing the taxes directly, Matteo Renzi announced that it would be possible for his Government to act more solution-oriented by making certain amendments over the roots of the problem relating to the taxes instead of totally removing the collection of these taxes. First of all Renzi promised to deduce a tax worth of 10 billion Euros and added that this amount would be compensated through cutting down on the public expenditures (http://www.bbc.com). On the other hand, having expressed that the "Regional Production Tax" which is called as "IRAP" and taken with a rate of 3.9\% from the net value created in the region by the regional authorities belonging to twenty administrative regions of Italy would be now decreased to a rate of $3.5 \%$ made many companies happy. It was announced that the tax deductions that would be performed in IRAP by the government would be financed over the income acquired from the taxation of financial instruments that was $20 \%$ previously excluding government bonds, by increasing it to $26 \%$ (International Tax Service 2014:1). 
In addition Renzi had the new elections act called as "Italicum" passed in the parliament in 2015 May. According to this act in Italy, where the past twenty years was governed mostly by the wide coalition and alliance governments and four different governments, one being a technocrat, held office with the impact of economic and political crisis in the last four years, the act in question was claimed to decelerate executive and legislative branches in the country and it was offered to have a single political movement instead of coalition governments to take office for five years.By this means, it was aimed to avoid the creation of economic fluctuations in the market by preventing the political instability (http://www.italy24.ilsole24ore.com).

Also starting reform preparations in the banking sector, Renzi Government planned, though its content was not certain yet, to change the banking laws that was providing equal voting right to the shareholders in the common banking system of Italy. Getting ready to create the opportunity for the Italian banks to merge within themselves due to Italian banks having the tendency to be sold to foreigners, Renzi Government defended that as a result the Italian banks would have an increase in their competitive power. It was planned especially for the big banks of Italy - such as Monte dei Paschidi Siena and UBI Bank - to take steps for them to merge (Unmack, 2015).

\section{Conclusion}

With the inclusion of Italy into the European Union, the problems that accelerate every passing day reached to complicated dimensions. Especially the economic structure of Italy, having difficulty in adapting to the requirements brought in by the union, deteriorated day by day and it dragged the country into a debt crisis. On the other hand, because of the political authority weakness and lack of inspection that had been dominant for many years the increased corruption and mafia activities found increasingly in the country revealed the necessity for a significant structural transformation of the country. In addition to that, Italy's economic structure being comprised of small and medium-scaled companies and that it could not reach to the competitive power in the standards of other European Union countries caused the country to face a long-term growth problem. Particularly not being able to create innovation and having low-technology production, created a gradual course of decrease in the growth numbers of Italy, which had been experiencing competition loss for many years in the face of many European countries with Germany being the main one.In this regard, Italian economy, being already in need for radical changes, also felt the need for solution-oriented reforms.

Hence in the year 2011 with the resignation of Selvio Berlusconi, who had been a part of Italian politics for twenty years, in their policies for solving the crisis, the governments following Berlusconi structural reforms were given priority. First of all, a series of precaution packages were established for the technocrat Mario Monti Government to escape from the difficult situation the country was in. In the reform packages that had mainly austerity policies, the changes dealing especially with the tax and retirement system drew the attention.Having succeeded in important changes in general terms, though these moves of Monti Government was met with positive reaction by the business communityit was mostly subjected to protests by the public.

Enrico Letta, who took office after Monti Government, also stressed in the Senate the necessity of the reforms and defended that the obstacles before the country's progress would be eliminated. However unlike the views of Prime Minister Letta promising hope towards finding solutions of all the conventional problems of Italy, he interpreted the property act as outdated and caused loss of trust by announcing that the tax in question would not be collected.So much that in a period, when Italy Government needed the increase to be created in the field of income for getting rid of this vicious cycle of debt, it was questioned to what extent the Letta Government could find a solution to Italy's structural problems by removing the property tax. Later on, because of not being able to actualize many of the reforms I promised earlier, the government could not contribute to the Italy's strategies for overcoming crisis and experienced loss of trust.Thus, with the revelation of government crisis along with the environment of insecurity in the country, Prime Minister Enrico Letta announced that he resigned from his office as prime minister in February 2014.

Matteo Renzi, who assumed the office of prime minister after Letta, announced the reform packages he was planning on applying during his first speech in senate and stated that the government he was going to form would focus more on employment and growth rather than on austerity policies. Unlike the governments that came before him, Renzi Government contributed to the stability of the country by following more consistent policies. Havingfirstly passed the "Elections Act", which had the rule of single party for five years instead of coalition governments in order to prevent an environment of insecurity that was created in this country due to short-term governments, Matteo Renzi's this step became an important development for eliminating political stability in the country though it was not considered as democratic by the other coalition members in the parliament. On the other hand, having anounced that there would be deductions in the taxes that create a heavy burden on the public; Renzi Government said that this 
would be compensated by the deductions in the public expenditures. Having based the reforms it actualized and will actualize on sound bases, Matteo Renzi took a step in a way to prove that the tax deductions would be compensated through deductions to be made in the public expenditures and announced that there would be deductions at a reasonable rate in the salaries of the ambassadors working in the big embassies belonging to Italy abroad.

Taking steps towards establishing stability in economy in general and aiming to find radical solutions, Renzi Government started to change Italy's country profile image to the positive. In order to prevent the economic instability and frequent government crises that are dominant in the country caused by the arbitrary applications of the coalition governments for long years, the reform packages created by Renzi Government presents an solution-oriented image for saving Italy from the crisis.However the fact that the regulations provided by Renzi Government within its "Labor Act" will exploit the workers' rights and that the dismissals will be shaped by the arbitrary attitudes of the employers, evoked great reactions of especially work and labor unions. Though this step is presented in the statements made by the government as having been taken for the purpose of decreasing unemployment, it is understood that it was not the case from the still high rates of (12\%) unemployment and especially the youth unemployment (40.7\%) found in Italy.Still not being able to find permanent solutions towards unemployment, which became a structural problem of the country, is regarded as a significant deficiency of Renzi Government.In addition, the increase in the criticisms against the government concerning this deficiency also affirms this situation. On the other hand, having announced that he would consult to more promising applications for Italy in comparison to the governments before him, Prime Minister Renzi have not yet taken any serious steps towards the problem of public debt, which is one of the most important problems of Italy, and this can be evaluated as another insufficiency of Renzi Government.Besides, the fact that noninterest surplus subject, which has importance in terms of sustainability of the debt, is not focused so much brings to mind the possibility that the promises given for decreasing the debts are not really cared about.

Decreasing the amount of Italy's debt, which has reached significant figures by increasing cumulatively over the years, depends on the noninterest surplus to be achieved in the country. Regardless of the normal levels of country's noninterest surplus rate in the past two years in comparison to the other countries, this amount in reality is insufficient for a countries such as Italy that have big economies. When the rate of noninterest surplus over the country's GDP recorded in the year 2014 is analyzed, it seen around the rate of $1.7 \%$. This rate is almost the same with the noninterest surplus rate applied by Germany.However in the light of Italy's much bigger debt burden in comparison to Germany, Italy must produce a higher rate of noninterest surplus. In that context, for Italy to get rid of this vicious cycle in debt, it has to produce noninterest surplus around the rate of $5 \%$ for at least ten years. Also with the full compatibility to the noninterest surplus policy that will be determined, being able to reveal the covered risk curtain over Italy's economy as a result of the decrease in convertibleness of debt stock will help the country to overcome its long-possessed growth and unemployment problems. Therefore in addition to the policies set forth by Italy for the purpose of finding solution to tax evasion and competitive power problems, which have become the chronic problems of the country, Italian Government must at once give importance to policies regarding noninterest surplus and actualize the applications to be determined in the fields in question.

\section{References}

Angelis, A. D. (2012). Anticorruzione, MarioMonti non temei numeri.Mailclima è cambiato, dopo il risveglio del Cav. Retrieved 25 June 2014, from http://www.huffingtonpost.it/2012/10/30/anticorruzione-monti-berlusconi_n_2044257.html

Barone, G., \& Narciso, G. (2012). Can The Mafia Divert The Allocation of Public Transfers?. Retrieved 5 January 2015, from http://www.voxeu.org/article/mafia-and-public-spending

Bohlen, C. (1996). North-South Divide in Italy: A Problem for Europe Too. Retrieved 15 November 2014, from http://www.nytimes.com/1996/11/15/world/north-south-divide-in-italy-a-problem-for-europe-too.html

Cencig, E. (2012). Italy'sEconomy in the Euro ZoneCrisisandMonti's Reform Agenda. StiftungWissenschaftundPolitik Berlin, 1, 54 .

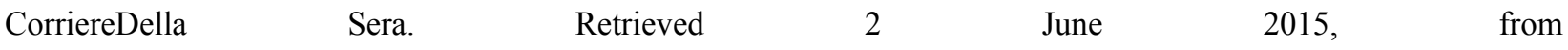
http://www.corriere.it/Primo_Piano/Politica/2011/08/12/pop_province.shtml

Dinmore, G., \& Segreti, G. (2013). Italy's Primier Give in to Berlusconi Tax Cut Demands. Retrieved 18 July 2014, from (http://www.ft.com/intl/cms/s/0/5d2ff4ea-108f-11e3-b29100144feabdc0.html\#axzz3cvVPhmxv

Eğilmez, M. (2012) .Euro Krizi' nin Nedeni. Retrieved 15 November 2014, from http://www.mahfiegilmez.com/2012/06/euro-krizinin-nedeni.html 
European Commission. (2007). One Currency for one Europe: The Road to the Euro. Retrieved 15 August 2015, from http://ec.europa.eu/economy_finance/publications/publication6730_en.pdf

European Commission. (2008). Overview of Family Business Relevant Issues Country Fiche Italy. Retrieved 21 December 2014, from http://ec.europa.eu/enterprise/policies/sme/files/craft/family_business/doc/familybusines_country_fiche_italy_e n.pdf

Floris, G. (2010). Seperati in Patria Nord Contro Sud: PerchéL'Italia é Sempre Più Divisa. Milano: Studio Editoriale Littera.

Gagliardi, C. (2014). Enrico Letta, Dimissioni Dopo La Direzione Pd: Renzi Premier? Si Apre La Crisi di Governo. $\begin{array}{lllll}\text { Retrieved } 18 & \text { July } & \text { 2015, from }\end{array}$ http://politica.excite.it/enrico-letta-dimissioni-dopo-la-direzione-pd-renzi-premier-si-apre-la-crisi-di-governo-N 147342.html

Governo Italiano. (2011). ConsigliodeiMinistri n.5 del 4/12/2011. Retrieved 18 June 2014, from http://www.governo.it/Governo/ConsiglioMinistri/dettaglio.asp?d=65675

Governo Italiano. (2012). Consiglio dei Ministri n.12 del 27/01/2012. Retrieved 18 June 2014, from http://www.governo.it/Governo/ConsiglioMinistri/dettaglio.asp?d=66448

Governo Italiano. (2013). Intervento del Presidente del Consiglio dei Ministri, EnricoLetta, alla Camera dei Deputati. Retrieved 18 July 2014, from http://www.governo.it/Presidente/Interventi/dettaglio.asp?d=74064

International Tax Service. (2014). ItalyReducesLocalCorporateTax, Increases With holding Tax on Financial Income. $\begin{array}{llll}\text { Retrieved } & 26 & \text { May } & \text { 2015, from }\end{array}$ http://www.pwc.com/en_US/us/taxservices/publications/insights/assets/pwc-italy-reduces-local-corporate-tax.p df

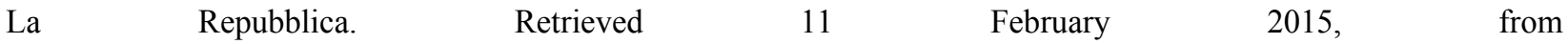
http://repubblica.it/politica/2011/11/12/direte/crisi12novembre-24884019/

Manasse, P. (2013). The Roots of the Italian Stagnation. Retrieved 12 October 2013, from $\mathrm{http}: / /$ www.voxeu.org/article/roots-italian-stagnation

Messia, H., \& Chance, M. (2011). Mario Monti Nominated To Replace Berlusconi. Retrieved 5 May 2015, from http://edition.cnn.com/2011/11/13/world/europe/italy-government/

$\begin{array}{lllll}\text { Normattiva. } & \text { Retrieved } & 19 & \text { June } & \text { 2015, }\end{array}$ http://www.normattiva.it/uri-res/N2Ls?urn:nir:stato:decreto.legge:2012-01-24;1

Trigilia, C. (2012). Why The Italian Mezzogiorno did not Achieve a Sustainable Growth: Social Capital and Political Constraint. Cambio: Rivista Sulle Trasformazioni Sociali, 4, 137-148.

Unmack, N. (2015). RollUp. Retrieved 25 May 2015, from http://www.breakingviews.com/renzi\%E2\%80\%99s-bank-reforms-can-solve-monte-paschi-mess/21181422.arti cle

\section{Internet References}

Retrieved 1 July 2015, from https://www.wsws.org/it/2013/apr2013/ital-a26.shtml

Retrieved 24 June 2015, from http://www.euronews.com/2012/04/18/italy-in-throes-of-labour-reform/

$\begin{array}{lllll}\text { Retrieved } 18 & \text { June } & \text { 2014, }\end{array}$ http://www.ilmessaggero.it/PRIMOPIANO/POLITICA/il_governo_monti_subito_al_lavoro_laquo_adesso_sar_ agrave_tutta_una_corsa_raquo_video/notizie/170120.shtml

Retrieved 19 June 2014, from http://www.unionelarioemonti.it/zf/index.php/servizi-aggiuntivi/index/index/idtesto/75

Retrieved $19 \quad$ June $2014, \quad$ from http://www.dirittobancario.it/news/interventi-normativi/decreto-liberalizzazioni-testo-pubblicato-in-gazzetta-uff iciale-nuovo-decreto-cresci-italia

Retrieved 25 December 2014, from http://ec.europa.eu/eurostat

Retrieved 25 December 2014, from http://www.soldionline.it/tag/rating/23

Retrieved 1 January 2015, from http://www.storiaestorici.it/index.asp?art=273/ 
$\begin{array}{llll}\text { Retrieved } & 16 & \text { May } & \text { 2015, }\end{array}$ http://www.ilfattoquotidiano.it/2014/02/21/governo-renzi-ecco-chi-sono-i-nuovi-ministri-le-schede/890135/

$\begin{array}{llll}\text { Retrieved } & 16 & \text { May } & \text { 2015, }\end{array}$ http://www.ilfattoquotidiano.it/2014/02/21/governo-renzi-ecco-chi-sono-i-nuovi-ministri-le-schede/890135/

$\begin{array}{llll}\text { Retrieved } 25 & \text { June } & \text { from }\end{array}$ http://www.tgcom24.mediaset.it/politica/scuola-sciopero-contro-la-riforma-matteo-renzi-ascoltiamo-protesta-_2 109616-201502a.shtml

Retrieved 5 July 2015, from http://archivio.internazionale.it/news/italia/2013/08/28/il-governo-letta-cancella-limu

Retrieved 5 July 2015, from http://www.italy24.ilsole24ore.com/art/lexicon/2014-07-16/italicum 155029.php?uuid=ABgyJKbB

$\begin{array}{lllll}\text { Retrieved } 25 & \text { July } & \text { from }\end{array}$
http://www.giornalettismo.com/archives/1800771/sciopero-5-maggio-2015-buona-scuola-orari-info/

Retrieved 26 July 2015, from http://www.bbc.com/news/world-europe-26549249

Retrieved 1 September 2015, from http://www.istat.it 